\title{
Litteratur
}

\section{Claudia Welz}

Love's Transcendence and the Problem of Theodicy. Religion in Philosophy and Theology 30. Tübingen: Mohr Siebeck 2008. XX + 437 s. $€ 74$.

Det er et voldsomt stort projekt, Welz har sat sig for i denne religionsfilosofiske afhandling. Bogens tematiske spændingsfelt er angivet i titlen og er for så vidt klassisk, men Welz sætter denne tematik ind $\mathrm{i}$ en usædvanlig og bredtfavnende ramme: Afhandlingen falder i tre dele. Hovedvægten ligger på Kierkegaard og den jødiske tænker Rosenzweig, der studeres i afhandlingens anden og mest omfangsrige del (ca. 200 s). Dette kernestykke i bogen er imidlertid 'pakket ind': Første del (90 s.) introducerer til klassiske positioner $\mathrm{i}$ forbindelse med teodicéspørgsmålet, men søger samtidig at placere denne diskussion i forhold til et spørgsmål om Guds fænomenalitet. Især i afsnittet om Husserl fremdrager Welz upubliceret materiale, der peger på en religionsfilosofisk åbning, der i al fald for denne læser er overraskende. Derved får hun samtidig knyttet en forbindelse til tredie del (godt 100 s.), hvor hun breder afhandlingen ud i dialog med visse franske fænomenologer. Dermed røbes afhandlingens egentlige ærinde: Ambitionen er at læse Kierkegaard og Rosenzweig ind i en kontekst, der ikke er deres, nemlig den nyere fænomenologis diskussion med, for ikke at sige overskridelse af, de grænser for fænomenologien, der udstikkes af Husserl og Heidegger. Denne ambition er understøttet af en art idéhistorisk parallelitet, i den forstand at ligesom Lévinas, Derrida og Marion tager afsæt i fænomenologien, men - hurtigt sagt - søger at overskride dens binding til det transcendentale subjekt, således formulerer Kierkegaard og Rosenzweig sig inden for, men også i en overskridende opposition til, den tyske idealisme. Den gudserfaring, som teodicéproblemet springer af, kan således spilles ind som en kvalificeret religionsfilosofisk udfordring til fænomenologiens erfaringsbegreb: På den ene side kan Gud ikke stå til ansvar for den menneskelige fornufts tribunal, fordi det ville svare til at reducere Gud til et fænomen på linie med andre fænomener, på den anden side må en sådan afvisning af teodicéens traditionelle raison d'être kunne kvalificeres: Hvad vil det altså sige, at Gud erfares som nærværende/fraværende, og hvordan forstå disse erfaringer fænomenologisk? Kærlighedens transcendens går hånd $\mathrm{i}$ hånd med Guds ikke-fænomenalitet, og peger på en ambivalens, der bryder det lukkede 'moderne' subjekt op. I læsningen af Kierkegaard og Rosenzweig er det ledende spørgsmål for Welz således ikke, hvordan disse forsvarer Gud, men omvendt: Interessen retter sig mod deres grunde for $i k k e$ at forsvare Gud. Welz strukturerer i øvrigt sin diskussion af Kierkegaard og Rosenzweig ganske hårdhændet ud fra bestemte fastlagte spørgsmål. Denne næsten 'komparative' fremgangsmåde gør stoffet håndterbart, og de ledende indfaldsvinkler er velbegrundede, men det forekommer også, at en sådan tilgang undertiden fungerer som stop- 
klods for hendes tolkning. Afhandlingens tredje del fører diskussionen over på (nogle af) de tænkere, der er blevet forbundet med eller anklaget for at propagere fænomenologiens "teologiske vending" i Frankrig. Det er gavens tematik, der både binder denne del sammen internt og lader "kærlighedens transcendens” indtræde i nyt lys. Det handler om Lévinas' radikale etik og kritik af 'totaliteten', om den sene Derridas kritik af gaven og økonomien, og om Marions forsøg på at lancere 'givetheden la donation' som fænomenologiens yderste horisont. Især Lévinas-afsnittet finder jeg spændende Welz trækker nogle frapperende tråde mellem ham og Kierkegaard - mens jeg er noget mere skeptisk over for hendes diskussion af Derrida og Marion, der munder ud i, at den ene er 'for lidt' og den anden 'for meget': Derrida bedømmes slet og ret som relativist (350), mens Marion exponeres som en art katolsk fundamentalteologisk overgreb på fænomenologien (369). Welz tillader dem ikke at levere en udfordring til hendes i øvrigt imponerende og grundige afhandling.

Henrik Vase Frandsen

\section{Albrecht Grözinger}

Homiletik. Lehrbuch Praktische Theologie. Band 2. Gütersloh: Gütersloher Verlagshaus 2008. 344 s. € 22,95.

Grözingers homiletik er en del af Güterslohs lærebogsserie i Praktisk Teologi. Dens intenderede læsere er universitetsstuderende, som ikke kan forvente efter endt studium at være 'udlærte prædikanter', men derimod at have erhvervet det, som Grözinger kalder "en sensibilitet for den homiletiske proces”- eller med andre ord en indsigt i denne særlige kommunikationsform, nogle af dens forudsætninger og udfordringer her og nu; og som tænkes at arbejde videre i en mere praktisk orienteret læring med dertil hørende anderledes lærebøger. Bogen er struktureret i fem kapitler: 1. Homiletiske perspektiver, som fremstiller og diskuterer religionens ændring og ændrede vilkår. 2. Homiletiske situationer og positioner, der foretager nedslag i de dele prædikenens og homiletikkens historie, som fortsat har betydning. 3. Den homiletiske kommunikationsbegivenhed inddrager kommunikationsteoretiske perspektiver på prædikenens talehandling, tilhørerne, prædikanten og de bibelske tekster. 4. Predikenens udformning (Gestaltung) drøfter retorik, narrativitet og poetik, som de væsentlige områder for prædikenens tilblivelse og fremførelse og medtænker både aktuel kultur og kristendommens egen diversitet samt mediesamfundet som vilkår. 5. Predikenens performans er kapitlet, hvor meget af det der også kunne være omhandlet kort diskuteres, såsom den gudstjenstlige kontekst, prædikenanalyse, og kasualprædikenen.

Grözingers udgangspunkt er, at prædikenen ikke længere hverken teologisk eller $\mathrm{i}$ henseende til berøringsflade på nogen måde har en privilegeret status i forhold til andre former for kommunikation af evangeliet i liturgi, sjælesorg, undervisning etc., og at netop det stiller spørgsmålet om dens ak- 